\title{
Eradication of the fungus Epichlö̈ coenophiala from Schedonorus arundinaceus (tall fescue) seeds by interrupting the vertical transmission process
}

\author{
Lucas R. Petigrosso ${ }^{1, \bigotimes}$; Osvaldo R. Vignolio; Ignacio Damiano;'M. Mercedes \\ Echeverria ${ }^{1}$; Mabel N. Colabelli' ${ }^{1}$ \& Pedro E. Gundel
}

\author{
${ }^{1}$ Facultad de Ciencias Agrarias, Universidad Nacional de Mar del Plata, Balcarce, Argentina. ${ }^{2}$ Facultad de Agronomía, \\ Universidad de Buenos Aires - IFEVA (CONICET). Buenos Aires, Argentina.
}

\begin{abstract}
Aвstract. Tall fescue is usually infected by a fungal endophyte, responsible of livestock intoxication due to fungal alkaloids. An endophyte fungus grows in the apoplast of aboveground tissues and is vertically transmitted through the seeds. Disinfecting plants or clones not only is useful as a way of eliminating a dangerous microorganism from cultivars, but also for experimental purposes. However, not all fungicides are effective, and if they are, a waiting period must be respected in order to avoid confounding effects of the endophyte and the treatment. We subjected plants (ramets from four genotypes) to different doses of two fungicides, Almagor ${ }^{\circledR}$ (Triazole + Imidazole) and Amistar ${ }^{\circledR}$ (Methoxy-acrylate), and evaluated the endophyte persistence. Fungicides were pipette-poured on pseudostems' bases of each plant. Endophytic status was diagnosed in tillers that received the fungicide and in the new tillers produced by the plants and seeds. While Amistar $^{\circledast}$ had no detectable effect, Almagor ${ }^{\circledR}$ was $100 \%$ effective at all doses. The latter interrupted the verticaltransmission processes (5400 evaluated seeds were endophyte-free). Phytotoxic effects were not observed in seeds. Proportion of normal and abnormal seedlings depended only on plant genotype. Almagor ${ }^{\circledR}$ was effective in stopping the fungus from growing into reproductive buds when apical meristems were down on the bases. Use of Almagor ${ }^{\circledR}$ is promising on old pastures dominated by toxic tall fescue, with the purpose of enriching the soil seed-bank with endophyte-free seeds.
\end{abstract}

[Keywords: grass, fungal endophyte, infection, toxicity]

Resumen. Erradicación del hongo Epichloë coenophiala de Schedonorus arundinaceus (festuca alta) por interrupción del proceso de transmisión vertical. Usualmente, festuca alta está infectada por un hongo endófito responsable de la intoxicación del ganado por la presencia de alcaloides fúngicos. El hongo endófito crece por el apoplasto de los tejidos aéreos y se transmite verticalmente a través de las semillas. La desinfección de plantas o clones es útil para eliminar un microorganismo peligroso de los cultivares y también para realizar experimentos. Sin embargo, no todos los fungicidas son efectivos, y si lo son, se debe respetar un lapso de espera para evitar confundir efectos del endófito con los del tratamiento. Sometimos plantas (clones de cuatro genotipos) a diferentes dosis de dos fungicidas, Almagor ${ }^{\circledast}$ (triazol + imidazol) y Amistar ${ }^{\circledast}$ (metoxi-acrilato), y evaluamos la persistencia del hongo. Los fungicidas se aplicaron con una pipeta vertiendo el producto sobre la base de los pseudotallos. El análisis de endófito se realizó en los macollos que recibieron el fungicida como en los nuevos macollos producidos por las plantas y en semillas. Mientras que Amistar ${ }^{\circledR}$ no tuvo ningún efecto, Almagor ${ }^{\circledR}$ fue $100 \%$ efectivo a todas las dosis. Este último fungicida interrumpió el proceso de transmisión vertical (las 5400 semillas evaluadas estuvieron libres de endófito). No se observaron efectos fitotóxicos. La proporción de plántulas normales y anormales dependió sólo del genotipo de la planta. Almagor ${ }^{\circledR}$ fue efectivo para evitar que el hongo creciera y llegara a las yemas reproductivas cuando los meristemas apicales estaban abajo, en las bases. El uso de Almagor ${ }^{\circledR}$ es promisorio en pastizales dominados por festuca alta tóxica, a fin de enriquecer el banco de semillas del suelo con semillas libres de endófito.

[Palabras clave: gramínea, hongo endófito, infección, toxicidad]

\section{INTRODUCTION}

Schedonorus arundinaceus (Schreb.) Dumort [Syn. Festuca arundinacea Schreb., Lolium arundinaceum (Schreb.) S. J. Darbyshire, Schedonorus phoenix (Scop.) Holub], commonly known as tall fescue, is likely the most important perennial forage grass in temperate zones of the world (Gibson and Newman 2001; Lattanzi et al. 2007; Scheneiter et al. 2015). Although it is a high-quality forage species

Editora asociada: Marina Omacini $\bar{\square}$ petigrosso.lucas@inta.gob.ar; lpetigrosso@mdp.edu.ar with production in winter, two characteristics that make it crucial in forage production chains, it can present anti-quality factors such as fungal alkaloids. As other cool-season grasses, tall fescue is commonly associated to fungal endophytes that producing alkaloids, endow host plants with an anti-herbivory powerful mechanism (Clay and Schardl 2002; Saikkonen et al. 2013; Bastías et al. 2017). The common fungal endophyte in tall fescue is Epichloë 
coenophiala (formerly known as Neotyphodium coenophialum; Clavicipitaceae) (Leuchtmann et al. 2014) and it has been a serious problem in livestock production systems as the alkaloids (mainly ergovaline) are toxic to mammals, causing huge economic losses (Bacon et al. 1977; Hoveland 1993). Selection of tall fescue cultivars for persistence and productivity but free of fungal endophytes, is one alternative strategy of breeding (Bouton et al. 1993, 2001; Gundel et al. 2013a).

Different methods have long been explored to disinfect plants not only for breeding goals but also for experimental purposes, as it may be important to compare endophyte-infected and non-infected plant material within the same population genetic background (Gundel et al. 2010). Fungal endophytes usually lose viability first than the seeds; so, storing commercial seeds for a while (e.g., two years) has been used as a successful strategy to eliminate the endophyte before sowing the seeds. Although with some variation mainly associated to the storage environmental conditions (in terms of temperature and relative humidity), this pattern has been shown not only in tall fescue but also in perennial ryegrass (Lolium perenne L.) and annual ryegrass (Lolium multiflorum L.) (Siegel et al. 1984; Rolston et al. 1986; Welty et al. 1987; Gundel et al. 2009, 2012). Also, endophyte-infected seeds can be subjected to high temperature shock or submerged in warm water to kill the fungus without having a significant impact on the seed viability (Siegel et al. 1984; Williams et al. 1984; Gundel et al. 2013b). Certainly, all these treatments require conducting pilot experiments for optimizing the methods. Fungicides have been also used to kill the fungus on plants and seeds. For example, clones of endophyteinfected plants can be soaked in a fungicide solution (hydroponic treatment) to kill the fungus (e.g., see Hamilton and Faeth 2005). Besides, endophyte-infected seeds of tall fescue and perennial ryegrass treated with fungicides were effective to eradicate the associated fungal endophytes (Williams et al. 1984; Leyronas et a1. 2006). However, these treatments also showed some negative side-effects on seed germination (Siegel et al. 1984; Williams et al. 1984; Leyronas et al. 2006). Systemic fungicides of translaminar and contact mode of action have been successfully used on tall fescue and perennial grass plants (Williams et al. 1984; Cheplick et al. 2000; Saiga et al. 2003). However, although there is information on how to eradicate the fungal endophytes from seeds and plants, there is a poor understanding on the effects of the treatments in relation to the plant life cycle.

An endophyte fungus grows by the apoplastic space of the green tissues of the plant, tightly associated to apical and axillary buds in such a way that it is able to reach the vegetative (tillers) and reproductive (spikelets, flowers) multiplication structure as they are produced (Philipson and Christey 1986; Majewska-Sawka and Nakashima 2004; Sugawara et al. 2004; Liu et al. 2017; Zhang et al. 2017). The infection is asymptomatic and the growth coordination between the two partners is perfect as almost all the produced seeds by a host plant are endophyte-infected (Christensen et al. 2008; Schardl et al. 2004; Gundel et al. 2011). Nonetheless, failures in the transmission process have been reported and some studies have identified critical stages in which certain of the, above indicated, multiplicative structure of the grass can escape from the fungal infection (Gundel et al. 2008, 2011). During tillering, apical buds are at soil surface level differentiating leaves until vernalization requirements have been achieved (this certainly depends on the species) and increasing temperatures and long-days induce reproduction (Murphy and Briske 1992). At this stage, the fungal mycelium is concentrated in the apical buds and pseudostems' bases formed by the overlapped leaf sheaths (Liu et al. 2017). Thus, we propose this stage is optimal for applying a systemic fungicide and to achieve high efficacy in controlling the fungus.

The objective of the present work was to study the effects of two systemic fungicides (Amistar $^{\circledR}$ and Almagor ${ }^{\circledR}$ ) on the fungal endophyte persistence from tall fescue plants. The two fungicides were chosen because they are commercially used for controlling fungal diseases in crops and fruit plants. The active ingredient prochloraz, present in Almagor ${ }^{\circledR}$, was previously reported to be effective against fungal endophytes of tall fescue and perennial ryegrass but when applied on seeds (slurry method) or on roots (fungicide-drenched soil) (Latch and Christensen 1982; Williams et al. 1984; Leyronas et al. 2006). Here, we subjected adult plants to different fungicide doses and checked for the endophyte presence in the bases of the tillers and also in the produced seeds. Additionally, we evaluated for potential phytotoxic effects of the fungicides on plants' ability to produce new healthy tillers and 
their transgenerational effect on seeds and seedlings.

\section{Materials And Methods}

\section{Site of plant collection}

On December $11^{\text {th }}, 2015$, four S. arundinaceus plants (i.e., genotypes) were collected in an old pasture plot of $\sim 100$ ha placed in the "Arroyo Grande" ranch, Mar Chiquita county (3732' S - 57 $55^{\prime}$ W), Province of Buenos Aires, Argentina. The pasture has been under grazing by cattle and horses for more than 20 years (Petigrosso et al. 2013).

\section{Sampling of tall fescue plants}

Four tall fescue plants in vegetative stage were collected with roots, by digging $30 \mathrm{~cm}$ depth, and brought to the laboratory of the Unidad Integrada Balcarce (Facultad de Ciencias Agrarias, Universidad Nacional de Mar del Plata - Estación Experimental Agropecuaria INTA Balcarce, $37^{\circ} 45^{\prime} \mathrm{S}$ - 58 $18^{\prime} \mathrm{W}$ ). To make sure each plant was a different genotype, there was at least more than $50 \mathrm{~m}$ one from each other. In the laboratory, each plant genotype was split in 24 ramets (tillers with roots) that were individually transplanted into $3 \mathrm{~L}$ plastic pots (13.5 cm diameter x $14 \mathrm{~cm}$ depth) filled with soil [sieved and homogenised soil, horizon A of a Typical Argiudol $(\mathrm{P}=53$ ppm, Bray-1 method; OM=4.3\%; pH=6.5; N$\left.\left.\mathrm{NO}_{3}{ }^{-}=30.1 \mathrm{ppm}\right)\right]$. A total 96 (4 genotypes $\mathrm{x}$ 24 ramets) plants were placed outdoor in the experimental field and watered on demand to avoid stress. About a month later, each plant was confirmed to be endophyte infected. The endophyte mycelium was searched under microscope $(100 x)$ in the sheath of outermost healthy leaf of a tiller previously stained with alkaline rose bengal (Belanger 1996; Petigrosso et al. 2013).

\section{The experiment}

On July $18^{\text {th }}, 2016$, each plant, still in vegetative stage, was randomly assigned to a fungicide treatment. At the moment of treatment application, the mean number of tillers per plant was $24.75 \pm 1.85$ (SE). Two systemic fungicides were used (Amistar ${ }^{\circledR}$ and Almagor ${ }^{\circledR}$ ) with four doses each: 0 (no fungicide), 0.5 (half the commercial dose), 1 (the commercial dose), and 2 (commercial dose doubled) (Table 1). Fungicides were applied at rates equivalent to those used in diluted applications under field conditions, $300 \mathrm{~mL} /$ ha and $1250 \mathrm{~mL} /$ ha for Amistar ${ }^{\circledR}$ and Almagor $^{\circledR}$, respectively. Formulated product was mixed in distilled water to obtain the final fungicide concentrations (Table 1). The treatments consisted of pouring the product with a pipette $50 \mathrm{~mL}$ (Eppendorf Easypet ${ }^{\circledR} 3$ dispenser) on the crown of the plant ensuring the fungicide reaches the sheaths of the leaves of all tillers; tissues where the endophyte is mainly found (White et al. 1993). The total volume delivered on each plant was $50 \mathrm{~mL}$ that according to the mean tiller number per plant, it was about $2 \mathrm{~mL}$ per tiller. Control plants received $50 \mathrm{~mL}$ of distilled water. The application of treatments was done at midmorning on a sunny day. The plants had been well watered late in the day before.

After fungicide application, all the plants were periodically observed as to detect visual phytotoxicity symptoms. The production of tillers per plant was evaluated 90 days after the fungicide application. At the same time, the endophyte presence was checked on each plant for the assessment the fungicide effectiveness. Three tillers per plant (that received the fungicide and in the new tillers produced) were selected and removed from the crown. As before, the endophyte mycelium was searched under microscope in the sheath

Table 1. Information regarding the two systemic fungicides used in the experiment, pharmacological characteristics (chemical group and mode of action) and the concentrations of active ingredient (a.i.) in each dose. Dose 1 corresponds to the label dose.

Tabla 1. Información sobre los dos fungicidas sistémicos utilizados en el experimento, sus características farmacológicas (grupo químico y modo de acción) y las concentraciones de ingrediente activo (a.i.) en cada dosis. La dosis 1 corresponde a la dosis de la etiqueta

\begin{tabular}{|c|c|c|c|c|c|c|}
\hline \multirow[t]{2}{*}{ Fungicides } & \multirow[t]{2}{*}{$\begin{array}{l}\text { Chemical } \\
\text { group* }\end{array}$} & \multirow[t]{2}{*}{ Mode of action* } & \multirow[t]{2}{*}{$\begin{array}{c}\text { Concentration of active } \\
\text { ingredients* }\end{array}$} & \multicolumn{3}{|c|}{$\begin{array}{c}\text { Dose (mL a.i./1000 mL } \\
\text { of solution) }\end{array}$} \\
\hline & & & & $0.5 \mathrm{x}$ & $1 x$ & $2 x$ \\
\hline ALMAGOR $^{\circledR}$ & $\begin{array}{l}\text { Triazole }+ \\
\text { Imidazole }\end{array}$ & $\begin{array}{l}\text { Inhibition ergosterol } \\
\text { synthesis and respiration }\end{array}$ & $\begin{array}{c}\text { Tebuconazole } 10 \% \text {, Azoxystrobin } \\
5.6 \% \text {, Prochloraz } 20 \%\end{array}$ & 4.15 & 8.3 & 16.6 \\
\hline AMISTAR $^{\circledR}$ & $\begin{array}{l}\text { Methoxy- } \\
\text { acrylates }\end{array}$ & Inhibition of respiration & Azoxystrobin $25 \%$ & 1 & 2 & 4 \\
\hline
\end{tabular}

*Source: www.frac.info/docs/default-source/publications/frac-code-list/frac-code-list-2017-final.pdf 
of outermost healthy leaf previously stained with alkaline rose bengal (Belanger 1996; Petigrosso et al. 2013).

When the plants reached the reproductive state (by the beginning of the following summer), the produced panicles were harvested as they mature (genotype 1 was excluded because it did not produce seeds). All the panicles produced by a plant were harvested and stored in paper bags at $4{ }^{\circ} \mathrm{C}$. A sample of 20 seeds was randomly taken from each clone and evaluated for endophyte presence. The seed squash technique allowed a reliable assessment to determine the endophyte infection status of a seed (Card et al. 2011). The seed was imbibed in $\mathrm{NaOH}(5 \%)$ for at least $8 \mathrm{~h}$, stained with aniline blue or rose begal, and evaluated under microscope (Saha et al. 1988; Card et al. 2011).

On January $10^{\text {th }}, 2017,40$ seeds per plant were sown in plastic trays $(18 \mathrm{~cm}$ long $\mathrm{x}$ $14 \mathrm{~cm}$ width $x 5 \mathrm{~cm}$ depth) on moisture Whatman filter paper $(15 \mathrm{~mL}$ of distillate water). A total of 48 trays ( 3 genotypes $x 4$ doses $x 3$ ramets/replicates) were randomly arranged in a growth chamber set at a constant temperature of $20{ }^{\circ} \mathrm{C}$ and 8-16 h light/dark cycle. After two weeks of incubation, seeds and seedlings were classified according to the following criterion (ISTA 2008): normal seedlings (well-developed root system and intact coleoptile without damage), abnormal seedlings (seedlings which did not show the capacity for continued development), fresh seeds (non-germinated seeds during the trial, although they remained dormant with the potential to germinate and develop a normal seedling) and dead seeds (present soft and mouldy aspect). For the analysis, we focused only on normal and abnormal seedlings since they give information on potential effect of fungicide on growth and development. There were no differences in dead seeds among treatments (data not shown) and we did not perform any tests (e.g., tetrazolium) to separate dormant from dead seeds within the category 'fresh seeds'.

\section{Statistical analysis}

To test for the effects of fungicide type (Amistar $^{\circledR}$ and Almagor $\left.{ }^{\circledR}\right)$ and dose $(0,0.5,1$ and 2), and plant genotype (four genotypes), on the different response variables, we fitted generalized lineal models using specific distribution functions (Crawley 2007). The number of tillers per plant 90 days after the fungicide treatments was analysed with glm using a Poisson distribution (log link). For endophyte transmission to the seeds, the response variable was binary ( $1=$ infected, $0=$ uninfected) and the model used a binomial function (logit link) (stats package, glm function). Similarly, the proportion of normal ( 1 =normal, $0=$ non-germinated $)$ and abnormal ( 1 =abnormal, $0=$ non-germinated) seedlings was also analysed with a binomial function. In the last two cases, overdispersion was corrected using quasibinomial distribution. After fitting models, analysis of deviance was used in all cases to estimate the effects of factors. All analyses were performed using the open source statistical software R (R Development Core Team 2016).

\section{Results}

\section{Effects of fungicides on tiller production}

The number of tillers per plant increased during experimental period. Neither tiller mortality nor misshaped/distorted leaves were observed associated to either fungicide identity or dose (L. Petigrosso, personal observation). Tiller number per plant 90 days after treatment, depended on the main effects of genotype $\left(\mathrm{F}_{3.88}=10.243, P<0.001\right)$ and fungicide type $\left(\mathrm{F}_{1,94}=30.154, P=0.001\right)$ but not on the dose $\left(\mathrm{F}_{3,91}=0.225, P=0.878\right)$. Overall, the mean number of tillers per plant across all treatments was $48.42 \pm 3.20,55.04 \pm 4.10$, $68.25 \pm 3.48$ and $68.5 \pm 3.44$ for genotype 1 , 2,3 , and 4, respectively. Plants exposed to Almistar $^{\circledR}$ produced on average $51.43 \pm 2.23$ tillers while those exposed to Almagor ${ }^{\circledR}$ produced 68.66 \pm 2.74 (data not shown).

\section{Effects of fungicides on the endophyte vertical transmission}

Ninety days after fungicide treatments, all the plants were found to be colonized by fungal mycelium (data not shown). This suggests that neither the fungicide type nor the dose was able to fully disinfect the plants.

The infection status of the produced seeds (i.e., endophyte transmission efficiency) was found to be affected by the fungicide type in interaction with the dose $\left(X_{362}^{2}=0.002, P<0.001\right)$. Except control plants, all the ramets treated with the fungicide Almagor produced only endophyte free seeds (Table 2). Alternatively, all the plants treated with the three doses of Amistar ${ }^{\circledR}$, produced seeds in which fungal hyphae were observed (Table 2 ). 
Table 2. Percentage of endophyte infection in the produced seeds (i.e., endophyte transmission efficiency) by the different plant genotypes of Schedonorus arundinaceus $(2,3$ and 4$)$ treated with different doses $(0 x, 0.5 x, 1 x$ and $2 x)$ of the two fungicides (Almagor ${ }^{\circledR}$ and Amistar ${ }^{\circledR}$ ). Each value is the average of three ramets, 20 seeds evaluated per ramet. The genotype 1 is absent as it did not produce seeds. Dose 1 corresponds to the commercial dose.

Tabla 2. Porcentaje de infección endofítica en las semillas producidas (es decir, eficiencia de transmisión del endófito) por plantas de los diferentes genotipos $(2,3 \mathrm{y} 4)$ de Schedonorus arundinaceus tratados con diferentes dosis $(0 \mathrm{x}, 0.5 \mathrm{x}, 1 \mathrm{x}$ y 2x) de los fungicidas Almagor ${ }^{\circledast}$ y Amistar ${ }^{\circledast}$. Cada valor representa el promedio de tres clones, 20 semillas evaluadas por clon. El genotipo 1 está ausente ya que no produjo semillas. La dosis 1 corresponde a la dosis comercial.

\begin{tabular}{ccccc}
\hline Fungicide & Dose & \multicolumn{3}{c}{ Plant genotype } \\
& $(\mathrm{mL}$ a.i./1000 mL of solution $)$ & 2 & 3 & 4 \\
\hline Almagor $^{\circledR}$ & $0 x($ control) & $100 \%$ & $100 \%$ & $0 \%$ \\
& $0.5 \mathrm{x}$ & $0 \%$ & $0 \%$ & $0 \%$ \\
& $1 \mathrm{x}$ & $0 \%$ & $0 \%$ & $0 \%$ \\
Amistar $^{\circledR}$ & $2 \mathrm{x}$ & $0 \%$ & $0 \%$ & $100 \%$ \\
& $0 x($ control) & $100 \%$ & $100 \%$ & $100 \%$ \\
& $0.5 \mathrm{x}$ & $100 \%$ & $100 \%$ & $100 \%$ \\
& $1 \mathrm{x}$ & $100 \%$ & $100 \%$ & $100 \%$ \\
\hline
\end{tabular}

\section{Effects of fungicides on seed performance}

No interaction effects among factors were detected on the proportion of germinated seeds that became normal seedlings $\left(X_{2.51}^{2}=18.577\right.$, $P=0.105)$. It was found dependent on the plant genotype $\left(X_{2,60}^{2}=121.385, P<0.001\right)$ but irrespective of the fungicide type $\left(X_{2,59}^{2}=6.638\right.$, $P=0.216)$ and the dose $\left(X_{2,58}^{2}=1.052, P=0.616\right)$ (Figure 1, upper panel). On average, the normal seedling proportion was $52.24 \%$,
$75.71 \%$ and $49.60 \%$ for genotype 2,3 and 4 , respectively.

The proportion of abnormal seedlings was only affected by the genotype of the plant $\left(X_{2,60}^{2}=292.140, P<0.001\right)$ and not by the fungicide type $\left(X_{2.59}^{2}=282.150, P=0.143\right)$ not by the dose $\left(X_{2.58}^{2}=276.95, P=0.290\right)$ (Figure 1 , lower panel). On average, the abnormal seedling proportion was $19.67 \%, 11.92 \%$ and $21.31 \%$ for genotype 2,3 and 4 , respectively.
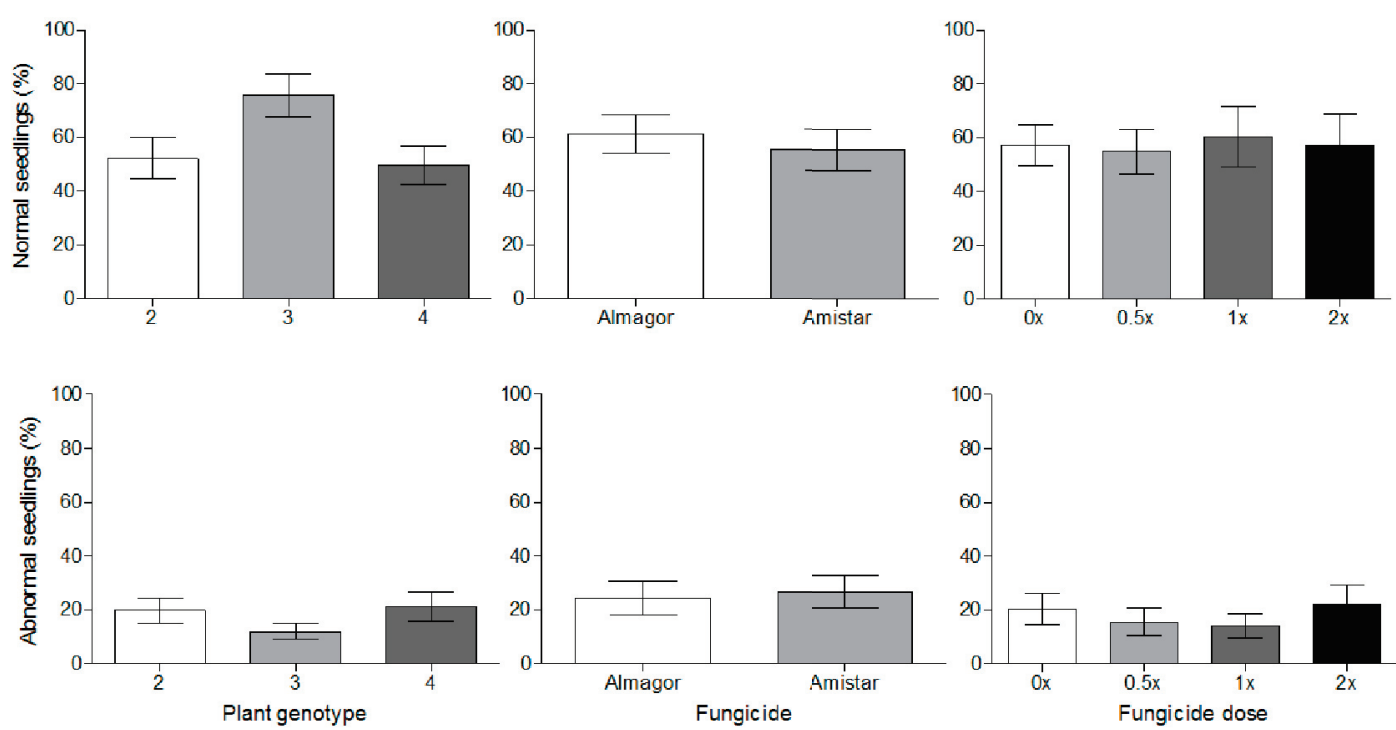

Figure 1. Mean effect of plant genotype of Schedonorus arundinaceus (2,3 and 4), fungicide type (Almagor ${ }^{\circledR}$ and Amistar $^{\circledR}$ ) and dose $(0 x, 0.5 x, 1 x$ and $2 x)$ on the percentage of germinated seeds that reached the state of normal seedling (upper panels) or abnormal seedlings (lower panel) in accordance with ISTA 2008. Values are mean $\pm 95 \%$ CI. Genotype 1 is absent as it did not produce seeds. Dose 1 corresponds to the commercial dose.

Figura 1. Efecto medio del genotipo de planta de Schedonorus arundinaceus (2, 3 y 4), tipo de fungicida (Almagor ${ }^{\circledR}$ Amistar $\left.^{\circledR}\right)$ y dosis $(0 x, 0.5 x, 1 x$ y $2 x)$ sobre el porcentaje de semillas germinadas que se convirtieron en plántulas normales (panel superior) o plántulas anormales (panel inferior) de acuerdo con ISTA 2008. Los valores corresponden a la media $\pm 95 \%$ IC. El genotipo 1 está ausente ya que no produjo semillas. La dosis 1 corresponde a la dosis comercial. 


\section{DisCUSSION}

We found that the two fungicides applied at the base of tillers had contrasting effects on the endophyte vertical transmission to the seeds. While the fungicide Amistar ${ }^{\circledR}$ did not affect the endophyte persistence, the fungicide Almagor ${ }^{\circledR}$ interrupted the transmission process of fungal endophytes from plant to the seeds. Independently of the dose, the fungicide Almagor ${ }^{\circledR}$ affected negatively the endophyte transmission to the seeds [notice that we checked the endophyte presence in 5400 seeds produced by plants from a combination of three fungicide doses and three plant genotypes (and three clones/replicates per treatments combination)]. Finally, we did not detect any phytotoxic effect on focus plants and their progeny. The variable number of normal and abnormal seedlings was only associated to plant genotype.

We are here showing for a first time that a fungicide applied on endophyte-infected mother plants, prevented the fungus to be found in the produced seeds. Nonetheless, we cannot ensure that the mother plants were completely clean of fungal endophyte since it is hardly impossible to scrutinize the individual as a whole. Beyond of understanding what happened exactly (whether there was an eradication of the fungus from the whole plant or if it was simply the transmission process interrupted), it is clear that the endophyte presented a high susceptibility to the fungicide Almagor $^{\circledR}$ at plant vegetative stage. In this stage of the plant, there is a high relationship leaf area/fungal mycelium, ensuring the fungicide is absorbed and translocated to the meristems. Our plants were well-watered and the fungicides were applied at midmorning, so the plants were actively functioning in terms of photosynthesis and transpiration. All these aspects have to be taken into account as to increase the chances of successfully apply the technique.

Previous reports exist showing differences in the effectiveness of fungicides to eliminate the endophytes from tall fescue plants. This could be due to different mode of action of fungicides and/or different metabolic mechanisms of tolerance or resistance present in fungi, as well as the genotype of plants and the environmental conditions under which they were growing (Saiga et al. 2003). In our experiment, the Amistar ${ }^{\circledR}$ fungicide, known for inhibiting the respiration, failed to eliminate the endophyte from the seeds. Alternatively, the Almagor ${ }^{\circledR}$ fungicide, even at the lowest dose, prevented the fungus to reach the seeds. Apart from inhibiting the respiration, Almagor ${ }^{\circledR}$ interrupt the synthesis of ergosterol, an essential molecule playing important structural and functional roles (Zhang and Rao 2010; Dupont et al. 2012). This is an important difference with the Amistar ${ }^{\circledR}$ formula, which lacks of prochloraz, the ergosterol synthesis inhibitor. Williams et al. (1984) reported that the eradication of endophyte Neotyphodium coenophialum from tall fescue seeds was effective by increasing the active ingredient of the fungicide (triadimefon). Saiga et al. (2003) reported that in N. lolii and N. coenophialum, endophytes of perennial ryegrass and tall fescue clones, respectively, the removal increased with the fungicide (benomyl and triforine) concentration.

Besides of affecting the fungi, a fungicide product can have effects on the plants; the so-called phytotoxic effects. We found no evidence of the two fungicides affecting either the mother plants or the seeds. Tiller production is a plant response variable that is usually promoted by the endophytic symbiosis (Belesky et al. 1987; Clay 1987; Cheplick et al. 2000). Here, we found that tiller number in mother plants varied across genotypes and was higher in plants treated with Almagor ${ }^{\circledR}$ than in plants treated with Amistar ${ }^{\circledR}$. Although we did not identify dormant and dead seeds, germination was on average high $(\sim 80 \%)$ and only associated to plant genotype. Of these germinated seeds, the proportion of normal seeds was about $60 \%$ and only associated to plant genotype. This is encouraging because Almagor ${ }^{\circledR}$ fungicide can be used as a chemical control to obtain endophyte-free seeds without affecting seed germination and seedling performance. For example, Williams et al. (1984) used different systemic fungicides to eradicate in tall fescue seeds the endophyte Acremonium coenophialum; although triadimenol was an effective fungicide, also affected seed germination. In our experiment, a genotype presented higher germination percentage than the other ones and it was not attributed to the fungicides. In synthesis, tall fescue-endophyte responses to experimental conditions are usually genotypespecific (Belesky et al. 1989; Belesky and Fedders 1996).

Almagor $^{\circledR}$ fungicide doses were effective in interrupting the vertical transmission of fungal endophytes in tall fescue plants. There were not observed phytotoxicity symptoms in all tall fescue plants (ramets by 
genotypes) in terms of tillers production, seeds germination and seedlings, when treated with this fungicide in the vegetative stage tillering. However, the response of tall fescueendophyte association was highly dependent on the plant genotype. This is the beginning to explore the use of Almagor ${ }^{\circledR}$ fungicide in toxic tall fescue-dominated pastures and grasslands to enrich soil seed-banks with endophyte-free seeds.
AcKnowledgements. The work was economically supported by the Projects 15/ A542 and AGR 540/17, funded by Facultad de Ciencias Agrarias, Universidad Nacional de Mar del Plata, Argentina. The authors thank to Lic. I. Erreguerena and Ing. Agr. M. Montoya for providing the fungicides. We also thank M.R. Desirello and S. Garfinkel for reading and making comments on an early version of the manuscript.

\section{REFERENCES}

Bacon, C. W., J. K. Porter, J. D. Robbins, and E. S. Luttrell. 1977. Epichloe typhina from toxic tall fescue grasses. Applied and Environmental Microbiology 34:576-581.

Bastías, D. A., M. A. Martínez-Ghersa, C. L. Ballaré, and P. E. Gundel. 2017. Epichloë fungal endophytes and plant defences: Not just alkaloids. Trends in Plant Science 22:939-948.

Belanger, F. C. 1996. A rapid seedling screening method for determination of fungal endophyte viability. Crop Science 36:460-462.

Belesky, D. P., J. D. Robbins, J. A. Stucdcmann, S. R. Wilkinson, and O. J. Devine. 1987. Fungal endophyte infectionloline derivative alkaloid concentration of grazed tall fescue. Agronomy Journal 79:217-220.

Belesky, D. P., W. C. Stringer, and N. S. Hill. 1989. Influence of endophyte and water regime upon tall fescue accessions. I. Growth characteristics. Annals of Botany 63:495-503.

Belesky, D. P., and J. M. Fedders. 1996. Does endophyte influence regrowth of tall fescue? Annals of Botany 78:499505.

Bouton, J. H., R. N. Gates, and C. S. Hoveland. 2001. Selection for persistence in endophyte-free Kentucky 31 tall fescue. Crop Science 41:1026-1028.

Bouton, J. H., R. N. Gates, D. P. Belesky, and M. Owsley. 1993. Yield and persistence of tall fescue in the south-eastern coastal plain after removal of its endophyte. Agronomy Journal 85:52-55.

Card, S. D., M. P. Rolston, Z. Park, N. Cox, and D. E. Hume. 2011. Fungal endophyte detection in pasture grass seed utilising the infection layer and comparison to other detection techniques. Seed Science and Technology 39:581592.

Cheplick, G. P., A. Perera, and K. Koulouris. 2000. Effect of drought on the growth of Lolium perenne genotypes with and without fungal endophytes. Functional Ecology 14:657-667.

Christensen, M. J., R. J. Bennett, H. A. Ansari, H. Koga, R. D. Johnson, G. T. Bryan, W. R. Simpson, J. P. Koolaard, E. M. Nickless, and C. R. Voisey. 2008. Epichloë endophytes grow by intercalary hyphal extension in elongating grass leaves. Fungal Genetics and Biology 45:84-93.

Clay, K. 1987. Effects of fungal endophytes on the seed and seedling biology of Lolium perenne and Festuca arundinacea. Oecologia 73:358-362.

Clay, K., and C. Schardl. 2002. Evolutionary origins and ecological consequences of endophyte symbiosis with grasses. American Naturalist 160:99-127.

Crawley, M. J. 2007. The R Book. John Wiley and Sons, Ltd, West Sussex, UK.

Dupont, S., G. Lemetais, T. Ferreira, C. Philippe, P. Gervais, and L. Beney. 2012. Ergosterol biosynthesis: a fungal pathway for life on land? Evolution 66:2961-2968.

Gibson, D. J., and J. A. Newman. 2001. Festuca arundinacea Schreber (F. elatior L. ssp. arundinacea (Schreber) Hackel). Journal of Ecology 89:304-324.

Gundel, P. E., W. H. Batista, M. Texeira, M. A. Martínez-Ghersa, M. Omacini, and C. M. Ghersa. 2008. Neotyphodium endophyte infection frequency in annual grass populations: relative importance of mutualism and transmission efficiency. Proceedings of the Royal Society of London 275:897-905.

Gundel, P. E., M. A. Martínez-Ghersa, L. A. Garibaldi, and C. M. Ghersa. 2009. Viability of Neotyphodium endophytic fungus and endophyte-infected and noninfected Lolium multi orum seeds. Botany 87:88-96.

Gundel, P. E., M. Omacini, V. O. Sadras, and C. M Ghersa. 2010. The interplay between the effectiveness of the grassendophyte mutualism and the genetic variability of the host plant in an agronomic context. Evolutionary Applications 3:538-546.

Gundel, P. E., J. A. Rudgers, and C. M Ghersa. 2011. Incorporating the process of vertical transmission into understanding of host symbiont dynamics. Oikos 120:1121-1128.

Gundel, P. E., M. A. Martínez-Ghersa, and C. M. Ghersa. 2012. Threshold modelling Lolium multi orum seed germination: effect of Neotyphodium endophyte infection and storage environment. Seed Science and Technology 40:51-62.

Gundel, P. E., M. Helander, C. Casas, C. E. Hamilton, S. H. Faeth, and K. Saikkonen. 2013b. Neotyphodium fungal endophyte in tall fescue (Schedonorus phoenix): A comparison of three Northern European wild populations and the cultivar Kentucky-31. Fungal Diversity 60:15-24.

Gundel, P. E., L. I. Pérez, M. Helander, and K. Saikkonen. 2013a. Symbiotically modified organisms: non-toxic fungal 
endophytes in grasses. Trends in Plant Science 18:420-427.

Hamilton, C. E., and S. H. Faeth. 2005. Asexual Neotyphodium endophytes in Arizona fescue: a test of the seed germination and pathogen resistance hypothesis. Symbiosis 8:69-86.

Hoveland, C. S. 1993. Importance and economic significance of the Acremonium endophytes to performance of animals and grass plant. Agriculture, Ecosystem and Environment 44:3-12.

ISTA. 2008. International Rules for Seed Testing. ISTA. Bassersdorf, Germany. Pp. 8-31.

Latch, G. C. M., and M. J. Christensen. 1982. Ryegrass endophyte, incidence, and control. New Zealand Journal of Agricultural Research 25:443-448,

Lattanzi, F. A., A. Mazzanti, and M. H. Wade. 2007. Seasonal animal production of temperate and Mediterranean tall fescue cultivars under continuous variable stocking with close control of sward state. Australian Journal of Agricultural Research 58:203-213.

Leuchtmann, A., C. W. Bacon, C. L. Schardl, J. F. Jr. White, and M. Tadych. 2014. Nomenclatural realignment of Neotyphodium species with genus Epichloë. Mycologia 106:202-215.

Leyronas, C., B. Mériaux, and G. Raynal. 2006. Chemical control of Neotyphodium spp. Endophytes in perennial ryegrass and tall fescue seeds. Crop Science 46:98-104.

Liu, J., P. Nagabhyru, and C. L. Schardl. 2017. Epichloë festucae endophytic growth in florets, seeds, and seedlings of perennial ryegrass (Lolium perenne). Mycologia 109:691-700.

Majewska-Sawka, A., and H. Nakashima. 2004. Endophyte transmission via seeds of Lolium perenne L.: immunodetection of fungal antigens. Fungal Genetics and Biology 41:534-541.

Murphy, J. S., and D. D. Briske. 1992. Regulation of tillering by apical dominance: chronology, interpretive value, and current perspectives. Journal of Range Management 45:419-429.

Petigrosso, L. R., M. N Colabelli, O. N. Fernández, V. Ispizúa, and M. G. Cendoya. 2013. Incidence of the endophyte fungus Neotyphodium coenophialum in pastures of tall fescue differing in age and soil characteristics. African Journal of Agricultural Research 8:2655-2662.

Philipson, M. N., and M. C. Christey. 1986. The relationship of host and endophyte during flowering, seed formation, and germination of Lolium perenne. New Zealand Journal of Botany 24:125-134.

R Development Core Team. 2016. R: A language and environment for statistical computing. R Foundation for Statistical Computing, Vienna, Austria.

Rolston, M. P., M. D. Hare, K. K. Moore, and M. J. Christensen. 1986. Viability of Lolium endophyte fungus in seed stored at different moisture contents and temperature. New Zealand Journal of Experimental Agriculture 14:297-300.

Saha, C. D., M. A. Jackson, and J. M. Johnson-Cicalese. 1988. A rapid staining method for detection of endophytic fungi in turf and forage grasses. Phytopathology 78:237-239.

Saiga, S., Y. Kodama, H. Takahashi, and M. Tsuiki. 2003. Endophyte removal by fungicides from ramets of perennial ryegrass and tall fescue. Grass and Forage Science 48:504-509.

Saikkonen, K., P. E. Gundel, and M. Helander. 2013. Chemical ecology mediated by fungal endophytes in grasses. Journal of Chemical Ecology 39:962-968.

Schardl, C. L., A. Leuchtmann, and M. J. Spiering. 2004. Symbioses of grasses with seedborne fungal endophytes. Annual Review of Plant Biology 55:315-340.

Scheneiter, J. O., I. I. Kaufmann, A. R. Ferreyra, and R. T. Llorente. 2015. The herbage productivity of tall fescue in the Pampas region of Argentina is correlated to its ecological niche. Grass and Forage Science 71:403-412.

Siegel, M. R., M. C. Johnson, D. R., Varney, W. C. Nesmith, R. C. Buckner, L. P Bush, P. B. Burrus, T. A. Jones, and J. A Boling. 1984. A fungal endophyte in tall fescue: Incidence and dissemination. Phytopathology 74:932-937.

Sugawara, K., H Ohkubo, Y. Mikoshiba, and M. Yamashita. 2004. Flowers for Neotyphodium endophytes detection: a new observation method using flowers of host grasses. Mycoscience 45:222-226.

Welty, R. E., M. D. Azevedo, and T. M. Cooper. 1987. Influence of moisture content, temperature, and length of storage on seed germination and survival of endophytic fungi in seeds of tall fescue and perennial ryegrass. Phytopathology 77:893-900.

White, J. F. Jr., G. Morgan-Jones, and A. C. Morrow. 1993. Taxonomy, life cicle, reproduction and detection of Acremonium endophytes. Agriculture, Ecosystems and Environment 44:13-37.

Williams, M. J., P. A. Backman, E. M. Clark, and J. F. White. 1984. Seed treatments for control of the tall fescue endophyte Acremonium coenophialum. Plant Disease 68:49-52.

Zhang, W., S. D. Card, W. J. Mace, M. J. Christensen, C. R. McGill, and C. Matthew. 2017. Defining the pathways of symbiotic Epichloë colonization in grass embryos with confocal microscopy. Mycologia 109:153-161.

Zhang, Y. Q., and R. Rao. 2010. Beyond ergosterol: linking pH to antifungal mechanisms. Virulence 1:551-554. 